\title{
Diatom Assemblage in a Tropical Lake of Northeastern Brazil
}

\author{
Lilian Rodrigues do Nascimento ${ }^{1 *}$, Abdelfettah Sifeddine ${ }^{1,2}$, Lezilda Carvalho Torgan ${ }^{3}$ and \\ Ana Luiza Spadano Albuquerque ${ }^{1}$ \\ ${ }^{I}$ Departamento de Geoquímica Ambiental; Instituto de Química; Universidade Federal Fluminense; Outeiro São \\ João Batista s/ $n^{o}$; Niterói - RJ - Brasil. ${ }^{2}$ Institute Recherche Development; Bondy - France. ${ }^{3}$ Museu de Ciências \\ Naturais; Fundação Zoobotânica do Rio Grande do Sul; Porto Alegre - RS - Brasil
}

\begin{abstract}
The composition and spatial variation of diatom assemblage in surface sediments of Caçó Lake (shallow, mesotrophic and weakly acid lake - Maranhão State, Brazil) were analyzed in order to know the distribution pattern of the species along the lake during rainy season (April 1999). Four zones were established in the lake based on 21 diatoms species and habitat affinities. The first three zones (prime three meters deep to six meters deep) were marked by the occurrence of Pinnularia gigas, Frustulia rhomboides, Encyonopsis krasskei, Eunotia camelus, E. femoriformis and E. monodon. Zone IV (seven to nine meters deep) was inhabited mainly by Surirella biseriata and Fragilariforma floridana. During the beginning of the rainy season, the diatom assemblage in Caço Lake was composed mainly by benthic and epiphytic forms that reflected the low lake levels and the abundance of littoral vegetation present in this lake.
\end{abstract}

Key word: diatoms, shallow lake, surface sediments, Caçó Lake, Brazil

\section{INTRODUCTION}

Lakes are intricately tied to the climate system, and their water level and chemistry are a manifestation of the balance between inputs (precipitation, stream inflow, surface runoff, groundwater inflow) and outputs (evaporation, stream outflow, ground water recharge) according to Mason et al. (1994). Changes in a hydrological budget can be caused by either climatic change or human activity and have the potential to alter lake level, hydrochemistry, hydrodynamic, and nutrient dissolution the lakes. These, in turn, may affect the physiological responses and species composition the lake's biota, including the diatoms (Fritz et al., 1999).

Diatoms are extremely sensitive to conditions prevailing in different aquatic conditions (Gasse et al., 1983). The use of diatom as indicators of environmental quality in rivers, lakes and streams is important for three basic reasons: their importance in ecosystems, their utility as indicators of environmental state, and their fundamental role in food webs (Jan Stevenson and Pan, 1999). For these reasons, the study of the composition and abundance of the diatoms can give valuable information about the extension and temporal variation of the littoral and pelagic zones

*Author for correspondence: liliannascimento@geoq.uff.br 
in the aquatic environments. On the other hand, the diatoms are also used as indicator organisms of long-term ecological perturbations, such as climatic changes, eutrophication and acidification (Battarbee, 1986; Wolin and Duthie, 1999; Stoermer and Smol, 1999). However, uncertainties arise when attempting to reconstruct paleoenvironments based on diatoms records because a diatom assemblage preserved in sediments does not precisely correspond to the modern diatom flora (Jiang et al., 2004). Therefore, studies on diatoms from surface sediments and their relationships with the sedimentary environments of the region are necessary before carrying out paleolake reconstruction using fossil diatom records (Jiang et al., 2001; De Sève, 1999; Juggins, 1992).

Few data are available about diatoms on surface sediments in South America, mainly in shallow lakes which are common in Brazil. Caçó is located in northeastern Brazil, and its water level is supported by a seasonal rainy period and ground water input.

This study was carried out to examine the composition of the diatom assemblage on the surface sediment of a tropical lake from northeastern Brazil, (which has been subjected to seasonal fluctuations in water level), and to investigate the grade of response of diatoms distribution to the water level changes. Some data about diatoms in surface sediments are available in South America, such as Miretzky et al. (2002) in Chascomús Lake (Argentina) and Sylvestre et al. (2001) in Araruama lagoon (Brazil).

\section{MATERIAL AND METHODS}

Caçó Lake $\left(2^{\circ} 58^{\prime} \mathrm{S}, 43^{\circ} 25^{\prime} \mathrm{W}\right)$ is located in northeastern Brazil (Maranhão State, Fig. 1), 100 $\mathrm{km}$ from the Atlantic coast and about $120 \mathrm{~m}$ above sea level. It's corresponds in a valley that has enclosed in an SW-NE oriented former river valley within a dune field dating back to Pleistocene times (Jacob et al., 2004). The climate is tropical humid with 4 - 5 months of dry season. Mean annual temperature is $26-28^{\circ} \mathrm{C}$ and with annual precipitation of about 1500 to $1750 \mathrm{~mm}$, rainy season occurs mainly from to November to May, and it is controlled by the Intertropical Convergence Zone (ITCZ). Maximum lake depth varies between 9-12 $\mathrm{m}$ during the dry and wet season. The watershed modern vegetation ranges from "Restinga" (local steppe vegetation) to "Cerrado" (Savanna sandy vegetation) on eolian sand (Ceccantini and Ledru, 2000, Sifeddine et al., 2003). Caçó is shallow, slightly acidic, oligotrophic and a polymitic system. The vertical circulation of the water column is basically controlled by the constant action of trade winds in the region. These features associated to the coastal vegetation result in a marked biological zonation with development of four different habitats or biozones (Fig. 2). Zone 1 (the prime 3 meters) and zone 2 (3-4m deep) corresponds the littoral zone with macrophytes and a great amount of plants semi emerged and submerged. Zone 3 (between 5 and 6 meters deep) is characterized by the presence of exclusive submerged vascular vegetation. Finally, Zone 4 (from 7 to 9 meters deep) is characterized by scarce vegetation.

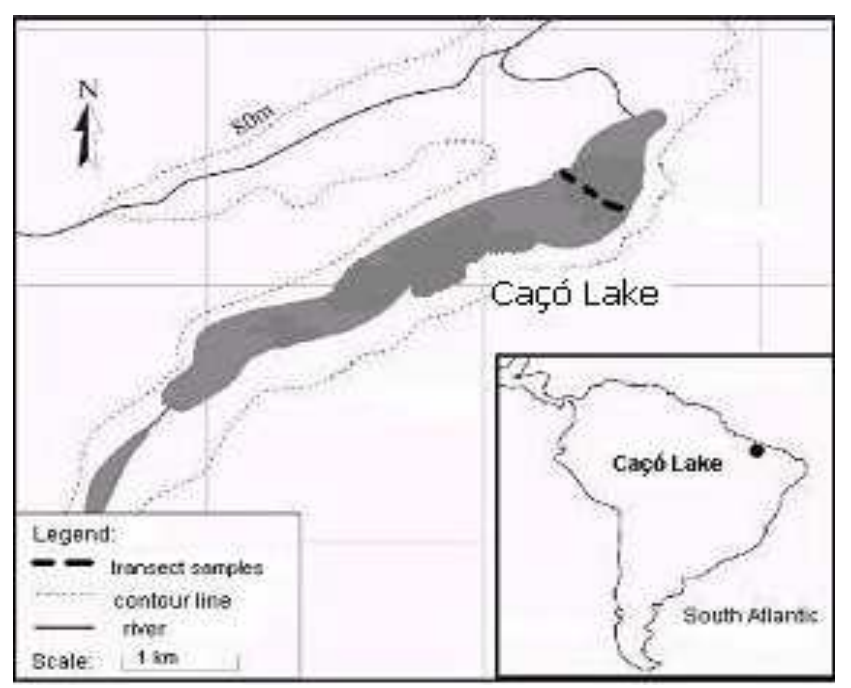

Figure 1 - Map of study area showing the location of transects samples. 


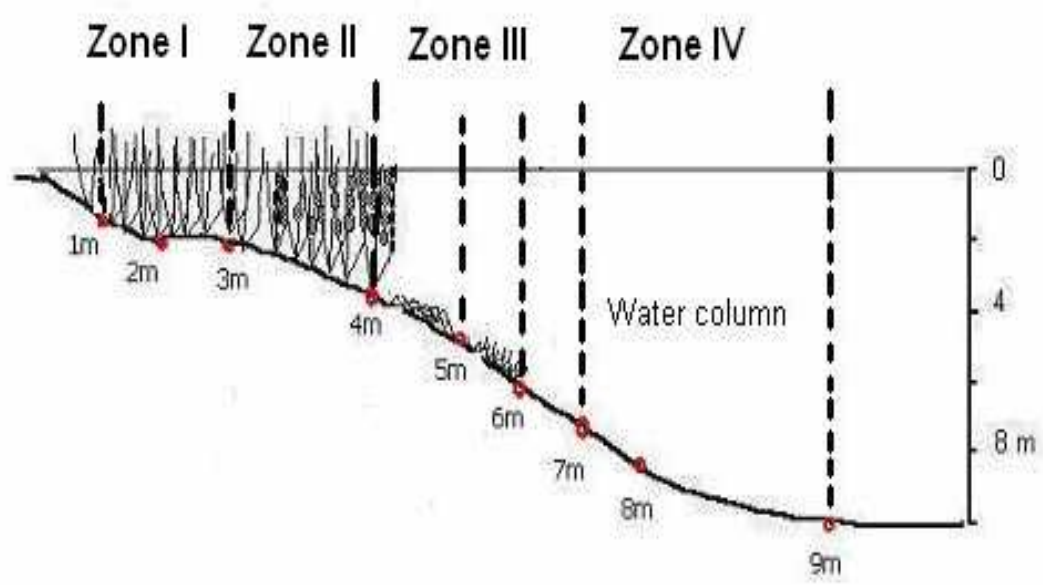

Figure 2 - Biological zonation and sites of the sampling zones on the Caçó Lake sediments.

\section{Sampling and Analysis}

Surface sediments samples were collected by scrapping the uppermost $1 \mathrm{~cm}$ from nine points in an area of nine meters, with collect on at one meter of distance each one along the bathymetric profile, in April 1999 (Fig. 2). About 2 g were homogenized and cleaned for diatom analysis by boiling in $30 \% \mathrm{H}_{2} \mathrm{O}_{2}$ and $70 \% \mathrm{HNO}_{3}$. Cleaned material was dried and about $0.4 \mathrm{~mL}$ was evaporated on the cover slips and mounted onto a glass slide with Naphrax for microscopic observation. Diatom identification were based on Meltzeltlin and Lange-Bertalot (1998), LangeBertalot (1996), Lange-Bertalot and Moser (1994), Krammer (1992), Krammer and Lange-Bertalot (1986-1991), Patrick and Reimer (1975, 1966). Water temperature $\left({ }^{\circ} \mathrm{C}\right)$ and $\mathrm{pH}$ were obtained with Horiba equipment, model U-10. Total phosphorus and Nitrate $\left(\mathrm{NO}_{3}{ }^{-}\right)$were determined by HPLC, according to Valderrama (1981). Surface sediments were not dated directly, but assumed that they represented the recent, because the diatom distribution generally fitted well into modern hydrological characteristics at the samples sites (Jiang et al., 2004). Qualitative and quantitative analysis were performed in chamber of $2 \mathrm{~mL}$, using Ütermohl method (1958) at a magnification of $400 \mathrm{X}$. When possible 300 valves were quantified to estimate the concentration of valves. $\mathrm{g}^{-1}$ (Gasse, 1992). The counting method was applied to the total assemblage, i.e, and dead and alive diatoms. The cluster analyses of the relative abundance of the diatoms along the horizontal profile depth were performed using STATISTICA 6.0.

\section{RESULTS}

Table 1 shows some physical and chemical variables of Caçó Lake in April 1999. During this period the water was acidic and demonstrated mesotrophic conditions (Dellamano et al. 2003).

The diatom assemblage of the surface sediments was formed by 21 diatoms infraspecific taxa listed in Table 2. Most of the species were in excellent state of preservation; a few of them were fragmented. In terms of preferential habitat, three diatoms groups were recognized: (1) benthic, (2) epiphytic, and (3) tycoplanktonic species. The epiphytic group was composed by 15 species and benthic and tycoplanktonic groups only 5 and 3 , respectively. 
Table 1 - Limnological variable of Caçó Lake, during the beginning of the rainy season (April, 1999).

\begin{tabular}{ccccc}
\hline Samples depth $(\mathbf{m})$ & Water Temperature $\left({ }^{\mathbf{0}} \mathbf{C}\right)$ & $\mathbf{p H}$ & Nitrate $\boldsymbol{\mu g} / \mathbf{L}$ & Total Phosphorus $\boldsymbol{\mu g} / \mathbf{L}$ \\
\hline 1 & 29.9 & 5.22 & 0.83 & 0.08 \\
2 & 30.4 & 5.22 & 0.22 & 0.59 \\
3 & 30.0 & 5.53 & 0.39 & 1.00 \\
4 & 29.1 & 5.40 & 3.50 & 0.06 \\
5 & 29.1 & 5.40 & 2.10 & 0.06 \\
6 & 28.4 & 5.50 & 0.63 & 0.21 \\
7 & 28.6 & 5.70 & 2.70 & 0.33 \\
8 & 29.9 & 5.75 & 0.35 & 0.87 \\
9 & 28.4 & 4.32 & 0.17 & 0.05 \\
\hline
\end{tabular}

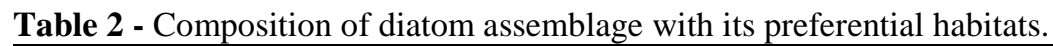

\begin{tabular}{|c|c|c|c|}
\hline Species & Benthic & Epiphytic & Tycoplanktonic \\
\hline Actinella brasiliensis Grunow & & & $\mathrm{X}$ \\
\hline \multicolumn{4}{|l|}{ Actinella guianensis Grunow } \\
\hline Brachysira brebissonii Ross & & $\mathrm{X}$ & $\mathrm{X}$ \\
\hline Brachysira kuntzei (Reichelt) Metzetlin and & & $\mathrm{X}$ & \\
\hline \multicolumn{4}{|l|}{ Lange-Bertalot } \\
\hline B. staurophora Souza \& Compère & & $\mathrm{X}$ & \\
\hline B. serians (Breb.ex Kutz) Round and Mann & & $\mathrm{X}$ & \\
\hline \multicolumn{4}{|l|}{ Encyonema neomesianum Krammer } \\
\hline Encyonopsis krasskei Krammer & & $\mathrm{X}$ & \\
\hline Eunotia camelus Ehrenberg & & $\mathrm{X}$ & \\
\hline E. femoriformis (Patrick) Hustedt & & $\mathrm{X}$ & \\
\hline E. monodon Ehrenberg & & $X$ & \\
\hline E. rabenhorstiana (Grunow) Hustedt & & $\mathrm{X}$ & \\
\hline \multicolumn{4}{|l|}{ Fragilariforma floridana (Hanna) Willian } \\
\hline Frustulia rhomboides Ehrenberg & & & $\mathrm{X}$ \\
\hline \multicolumn{4}{|l|}{ F. rhomboides var. saxonica (Rabh.) } \\
\hline De Toni & & $\mathrm{X}$ & \\
\hline F. undosa Lange-Bertalot & $\mathrm{X}$ & $\mathrm{X}$ & \\
\hline \multicolumn{4}{|l|}{ Gomphonema archaevibrio Lange-Bertalot and } \\
\hline Reichmann & & $\mathrm{X}$ & \\
\hline P. divergens var.undulata (Per. \& Ehr.) & $\mathrm{X}$ & $\mathrm{X}$ & \\
\hline Hustedt & $X$ & & \\
\hline P. gigas Ehrenberg & $X$ & & \\
\hline \multicolumn{4}{|l|}{ P. mesolepta (Ehr.) W.Smith } \\
\hline Surirella biseriata var. constricta (Breb.) & $\mathrm{X}$ & & \\
\hline Grunow & & & \\
\hline
\end{tabular}

Valves.g ${ }^{-1}$ concentrations of diatoms on surface sediment ranged from $4.00 \times 10^{4}$ to $5.85 \times 10^{4}$ valves.g ${ }^{-1}$ (Table 3, Fig. 3). These values were observed associated with high precipitation in the summer. A different pattern of distribution of diatoms density between the pelagic and littoral zone was observed in the horizontal sediment transect. At $4 \mathrm{~m}$ depth (the limit zone of the macrophytes colonization), the highest density $5.74 \times 10^{4}$ valves. ${ }^{-1}$ and highest richness (21 species), were observed (Fig. 3). Benthic and epiphytic species, such as Pinnularia, Frustulia and Encyonopsis were dominant in the pelagic zone. At the $5 \mathrm{~m}$ depth, tycoplanktonic species, especially Actinella and Fragilariforma were dominant. $^{-1}$ (Table 3). 
Table 3 - Density (valves. $\mathrm{g}^{-1}$ ), richness (number of species) and dominant species in the sampling depths of the Caçó Lake in April 1999.

\begin{tabular}{cccc}
\hline Depth $(\mathbf{m})$ & Total Density (valves/g) & Richness & Dominant species \\
\hline 1 & 485.970 & 16 & Pinnularia divergens $(32 \%)$ \\
2 & 472.875 & 16 & Pinnularia divergens $(35 \%)$ \\
3 & 480.150 & 15 & Frustulia rhomboides $(35 \%)$ \\
& & & Encyonopsis krasskei $(32 \%)$ \\
4 & 574.725 & 23 & Actinella guianensis $(25 \%)$ \\
5 & 468.510 & 12 & Actinella brasiliensis $(38 \%)$ \\
6 & 400.125 & 12 & Actinella guianensis $(38 \%)$ \\
7 & 462.690 & & Pinnularia divergens $(25 \%)$ \\
8 & 528.165 & 14 & Fragillariforma floridana $(24 \%)$ \\
& & & Surirella biseriata var. constricta $(21 \%)$ \\
9 & 493.245 & 13 & Fragillariforma floridana $(32 \%)$ \\
Gomphonema archeavibrio $(19 \%)$ \\
Gomphonema archeavibrio $(18 \%)$
\end{tabular}

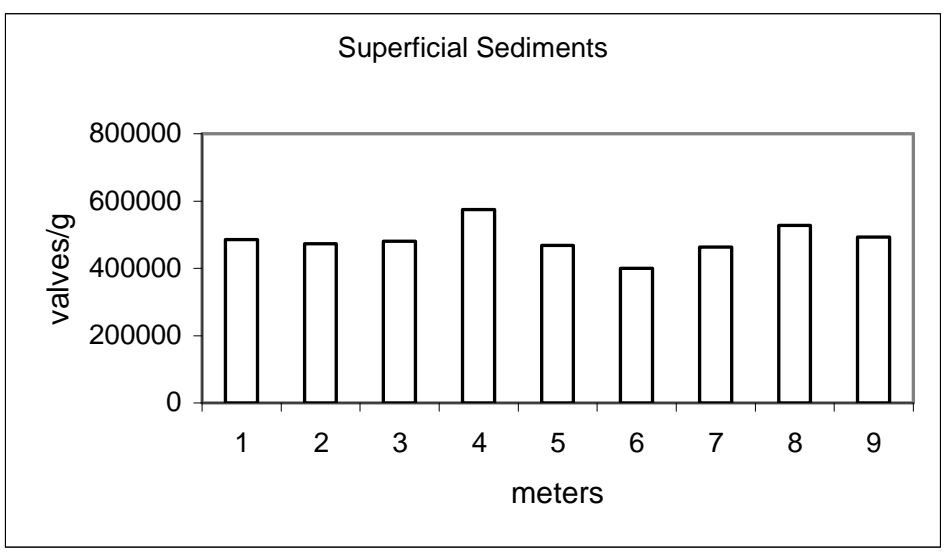

Figure 3 - Total cell density on the superficial sediments (valves. $\mathrm{g}^{-1}$ ).

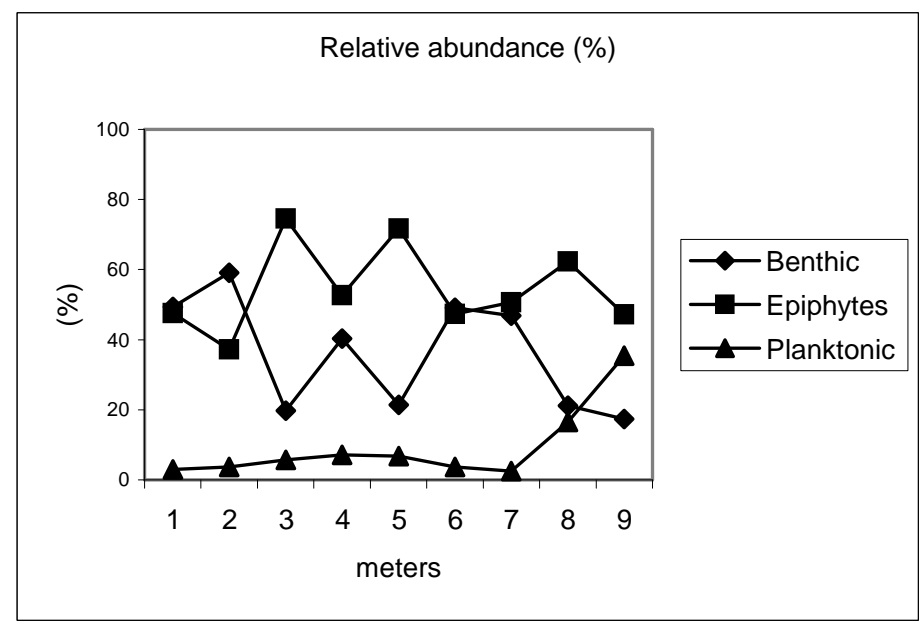

Figure 4 - Relative abundance (\%) of the groups by habitats. 
The benthic and epiphytic species were abundant at the initial levels of the littoral zone. Only the epiphytic species were abundant between 3 and 8 meters depth. Tycoplanctonic species were in low percentages along the horizontal profile and were abundant only at 9 meters depth.

Cluster analysis was applied to samples to characterize species distribution. Two distinct species groups were identified, $\mathrm{A}$ and $\mathrm{B}$, which were sub-divided into sub-groups (Fig. 5). Group A was formed by species which occurred in the first zones (I and II), and was also characterized by a massive occurrence of benthic and epiphytes species. Group B was formed by the epiphytes and tycoplanktonic taxa.

The first group (Group A, sub-group 1) was characterized by epiphytic and benthic taxa, such as Frustulia undosa and Pinnularia divergens in the first 1-2 m. Sub-group 2 was represented by Frustulia rhomboides and Pinnularia gigas. These species were observed along all zone I, i.e., from 1 to $3 \mathrm{~m}$. The Group A, sub-group 3 was formed by the epiphytic species such as Encyonopsis krasskei and the tycoplanktonic Actinella guianensis. These species were dominant along the zone II, around 4 meters depth. In this zone, macrophytes subemerged were dominant.

Group B, was also sub-divided into three subgroups. The sub-group 1 was composed by four species: epiphytic Brachysiraceae and Frustulia rhomboides var. saxonica observed at zoneIII (5 m depth) and the tycoplanktonic Fragilariforma floridana and the epiphytic Gomphonema archeavibrio that were found at zone IV (8 and 9 $\mathrm{m}$ depht). This group was characterized by an association of epiphytic-tycoplanktonic taxa. Subgroup B.2 was characterized by benthic and epiphytic taxa such as Pinnularia mesolepta, Surirella biseriata and Encyonema neomesianum, respectively, and their occurrence were restricted to the zone IV (7 meters depth). Sub-group B.3 was composed by Actinella brasiliensis, Pinnularia divergens var. undulatus and Surirella robusta var. constricta at zone III (6 meters depth).

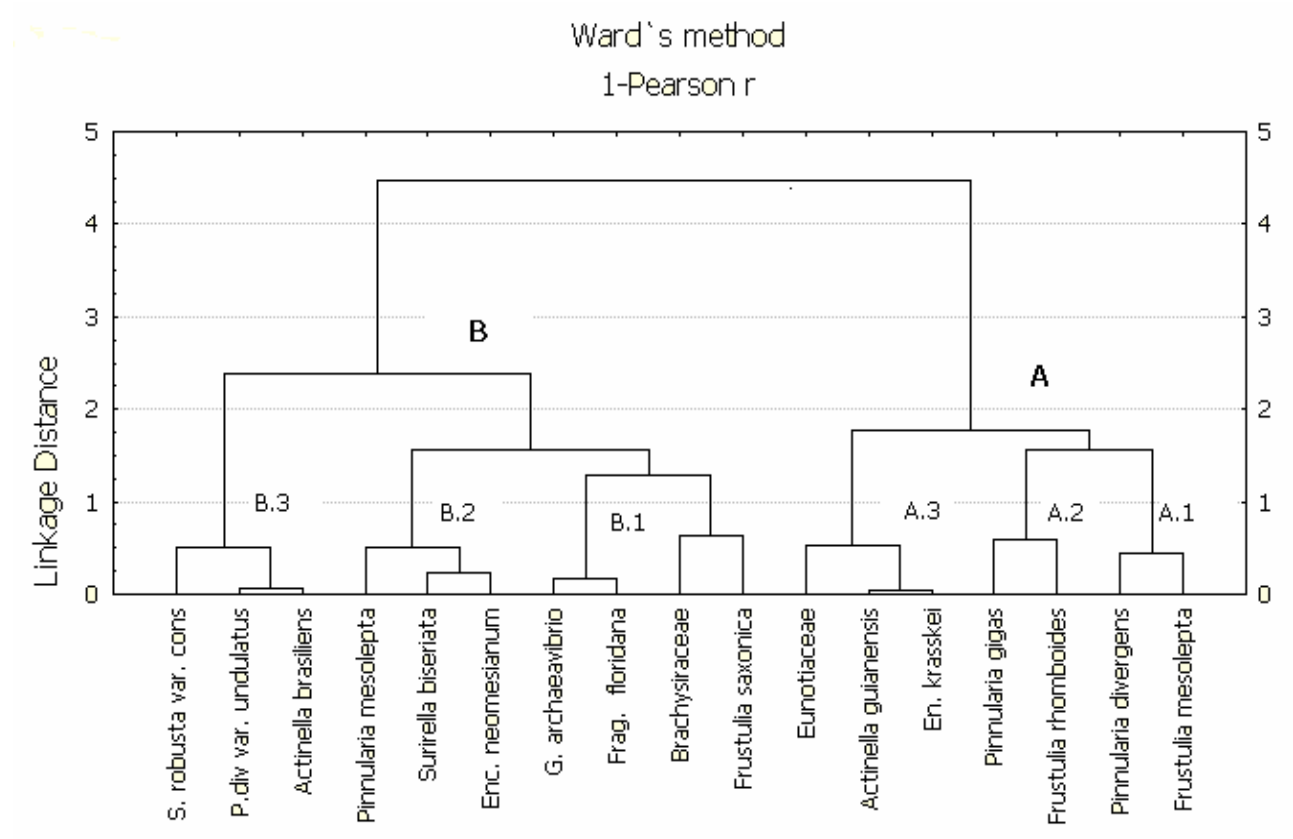

Figure 5 - Cluster analysis of the diatoms from the superficial sediments in Caçó Lake, April 1999.

\section{DISCUSSION AND CONCLUSION}

The modern diatom assemblage identified on the surface sediments of Caçó Lake was strongly dominated by cosmopolitan taxa adapted to acid, shallow waters, where trade wind results in a constant mixing of the water column. The spatial distribution of this diatom association in this lake 
observed along transects showed different zones in the horizontal profile. The lake showed a littoral zone that was characterized by macrophytes emerged and sub-emerged that supported the growth and maintenance of diatom assemblages dominated by benthic and epiphytic species, such as Pinnularia divergens, $P$. gigas, Brachysira brebissonii, B. kuntzei, B. serians, Eunotia camelus, E. femoriformis, E. monodon, $E$. rabenhorstiana. These assemblages reflected a relative shallow water body. The pelagic zone was characterized by Actinella brasiliensis, A. guianensis and Fragilariforma floridana.

The diatom distribution showed different associations related to the colonization by macrophytes, vascular vegetation and depths. Epiphytic species were the dominant group and were supported by abundance of macrophytes and vegetation located in the littoral zone of the lake. Statistical analysis showed that the productivity of the Caçó Lake was mainly concentrated on the margins, close to submerged and semi-emerged plants (Juncus sp.) growing between 1 and $4 \mathrm{~m}$ depth. These plants were used by diatoms as substrate for growth and maintenance. This demonstrated the intensive biotic interaction among the microalgae and macrophyte and vegetation stands. Diatoms were not a dominant class on total phytoplankton in Caçó Lake according to Dellamano-Oliveira et al. (2003), Chlorophyceae class contributed with highest density during the beginning of the rainy season.

In freshwater lakes, in general, changes in planktonic to non-planktonic ratio are often used to indicate the water level fluctuations (Gasse et al., 1989). In freshwater lakes, in general, changes in planktonic to non-planktonic ratio are often used to indicate water level fluctuations (Gasse et al., 1989). In Caçó lake, euplanctonic diatoms were not present, but the relation of tycoplanktonic and benthic species could be able to indicate changes in the horizontal distribution of the diatoms assemblage during the summer. These results demonstrated that at low-lake levels a high amount of epiphytic forms were present in the lake due the abundance the wide distribution of the vegetation in different zones of the lake. The use of the diatoms assemblages as indicators of lake depth in the Caçó Lake was possible and demonstrated as mentioned by Wolfe et al. (2001) that the depth distribution of diatom was controlled by the distribution of the aquatic vegetation in the lake.

\section{ACKNOWLEDGEMENTS}

The authors wish to thanks the colleague who collaborated with this work. Also thanks to $\mathrm{CNPq}$ and IRD (Institute Recherche Development, Bondy, France).

\section{RESUMO}

Com o objetivo de se conhecer a dinâmica espacial e a distribuição das diatomáceas contidas no sedimento superficial do lago Caçó, durante o período de chuvas (abril de 1999) foram realizadas coletas em um "transect" horizontal. A partir da observação destas coletas efetuadas a cada 1 metro pode-se observar que a distribuição das diatomáceas esteve fortemente ligada a ocorrência do banco de macrófitas da sua margem, com a ocorrência maciça das espécies epifíticas e bentônicas. A análise de agrupamento de dados permitiu uma melhor visualização, da sua distribuição a cada profundidade e também das associações específicas em cada zona. Os resultados deste estudo permitiram concluir que a ocorrência e distribuição das diatomáceas do Lago Caçó está fortemente ligada ao banco de macrófitas localizado em suas margens, definindo assim zonas características dentro do lago.

\section{REFERENCES}

Barker, P. (1994), Experimental dissolution of diatom silica in concentrated salt solution and implication for paleoenvironmental reconstruction. Limnology and Oceanography, 39, 99-110.

Battarbee, E.W. (1986), Diatom Analysis. In: Berglund, B.E. (ed) Handbook of Holocene palaecology and palaeohydrology. J. Wiley and Sons, New York, pp 527-570.

Ceccantini, G. and M.-P. Ledru. (2000). Panorama botânico do lago Caçó. Departamento de Geoquímica Ambiental da Universidade Federal Fluminense, Niterói, UFF, Workshop do Projeto Maranhão.

Dellamano-Oliveira, M.J., Senna, P.A.C. and Taniguchi, G.M. (2003), Limnological characteristics and seasonal changes in density and diversity of the phytoplanktonic community at the Caçó pond, Maranhão State, Brazil. Braz. Arch. of Biol. And Tech. 46 (4), 641-651.

De Sève, M.A. (1999).Transfer function between surface sediments diatom assemblages and sea- 
surface temperature and salinity of the Labrador Sea. Mar. Micropaleontol. 36, 249-267.

Hustedt, F. (1930), Bacillariophyta. In: Die Süßwasserflora von Mitteleuropa (A. Pascher, ed.), G. Fischer Jena. 10, 1-466.

Fritz, S.C.; Cummings, B.C.; Gasse, F. and K.F. Laird. (1999), Diatoms as a indicator of hydrologic and climate change in saline lakes. In: Stoermer, E.F. and Smol, J.P. (eds). The Diatoms: applications for the environmental and earth sciences. Cambridge University Press. Cambridge, pp. 41-73.

Gasse, F.; Talling, J.F. and P. Kilhan. (1983). Diatoms assemblages in East Africa: classification, distribution and ecology. Rev. Hydrobiol. 16, 3-34.

Gasse, F. Lédeé, V., Massault, M. and J-C. Fontes. (1989), Water level fluctuations of Lake Tanganyka in phase with oceanic changes during the last glaciation and deglaciation. Nature, 342, 57-59.

Gasse, F. (1992), Diatoms for reconstructing palaeoenvironments and palaeohydrology in tropical simi-arid zones. Example of some lakes from Niger since 12,000 BP. Hydrobiology. 154, 127-163.

Jacob, J., Disnard, J-R., Boussafir, M., Sifeddine, A., Turcq, B. and A.L.S. Albuquerque. (2004), Major environmental changes recorded by lacustrine sedimentary organic matter since last glacial maximum near the equator (Lagoa do Caçó, NE Brazil). Palaeogeography, Palaeoclimatology, Palaeoecology., 205, 183-197.

Jan Stevenson, R. and Y. Pan. (1999), Assessing environmental conditions in rivers and streams with diatoms. In: Stoermer, E.F. and Smol, J.P. (eds). The Diatoms: applications for the environmental and earth sciences. Cambridge University Press. Cambridge, pp.11-40.

Jiang, H.; Seidenkrantz, M -S; Knudsen, K.L. and J. Eriksson. (2001), Diatom surface sediment assemblages around Iceland and their relationships to oceanic environmental variables. Mar. Micropaleontol. 41, 73-96.

Juggins, S. (1992), Diatoms in the Thames estuary, England: ecology, paleoecology, and salinity transfer function. Bibl. Diatomol., 25, 1-216.

Krammer, K. (1992), Pinnularia: eine Monographie der europaichen Taxa. Bibliotheca Diatomologica, 26, 1353.

Krammer, K. and H. Lange-Bertalot. (1986-1991), Bacillariophyceae. In: Süßwasserflora von Mitteleuropa (H. Ette, J. Gerloff, H. Heynig and D. Molenhauer, eds.) Fischer, Stuttgart. 2, 1-4.

Lange-Bertalot, H. (1996). Iconographia Diatomologica. Koeltz Scientific Books v.4.284p.

Lange-Bertalot, H. and Moser, G. (1994), Brachysira. Monographie der Gattung. J. KRAMMER (ed.). Berlin, Stuttgart, 212.
Mason, I.M., Guskowska, M.A.J., and C.G. Repley. (1994), The response of lake levels and areas to climate change. Climatic change, 27, 161-197.

Meltzeltlin, D. and H. Lange-Bertalot. (1998), Tropical Diatoms of South America. Iconographia Diatomologica. Koeltz Scientific Books, 5, 235

Miretzky, P.; Maidana, N.I. and A.F. Cirelli. (2002), Stability of diatom compositionin a variable lake environment: Lake Chascomús, Argentina. Limnology., 3,77-85.

Patrick, R., and C.W. Reimer. (1975), The Diatoms of the United States. I - Monographs of the Academy of Natural Sciences of Philadelphia, 13, 688.

Patrick, R., and C.W. Reimer.(1966), The Diatoms of the United States. II - Monographs of the Academy of Natural Sciences of Philadelphia, 13, 213.

Sifeddine, A., Albuquqerque, A.L.S., Ledru, M-P, Turcq, B., Knoppers, B., Martin, L., Mello, W.Z, Passenau, H., Dominguez, J.M.L., Cordeiro, R.C., Abrão, J.J. and A.C.S.P. Bittencourt. (2003), A 21.000 cal years paleoclimatic record from Caçó lake, northern Brazil: evidence from sedimentary and pollen analyses. Palaeogeography, Palaeoclimatology, Palaeoecology. 189, 25-34.

Stoermer, E.F. and J.P. Smol. (1999), Application and uses of diatoms: Prologue. In: Stoermer E.F. and Smol, J.P. (eds). The diatoms: application for the environmental and earth sciences. Cambridge University Press, Cambridge, pp. 3-8.

Sylvestre, F.; Beck-Eichler, B.; Duleba, W. and J.P. Debenay. (2001), Modern benthic diatoms distribution in a hypersalinecoastal lagoon: the Lagoa de Araruama (RJ), Brazil. Hydrobiology., 443, 213231.

Utermöhl, U. (1958), Perfeccionamento del metodo cuantitativo del fitoplancton. Comum. Assoc. Int. Limnol. Teor. Apl., Michigan, 9, 89.

Valderrama, J. C. (1981), The simultaneous analysis of total nitrogen and phosphorus in natural waters. Marine Chemistry, 10, 109-122.

Wolfe, B.B., Aravena, R., Abbott, M.B., Seltzer, G.O. and Gibson, J.J. (2001), Reconstruction of paleohydrology and paleohumidity from oxygene isotope records in the Bolivian Andes. Paleo, Paleo, paleo 176, 177, 192.

Wolin J.A. and H. Duthie. (1999), Diatoms as indicator of water level change in freshwater lakes. In: Stoermer E.F. and Smol, J.P. (eds). The diatoms: application for the environmental and earth sciences. Cambridge University Press, Cambridge, pp 183-202.

Received: January 23, 2006; Revised: September 11, 2006; Accepted: October 01, 2009. 